$S D$ III. Q\&B
.1920

$\ln 1,-5 !$

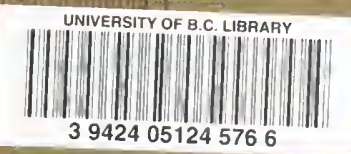

FORESTRY IN QUEENSLAND 


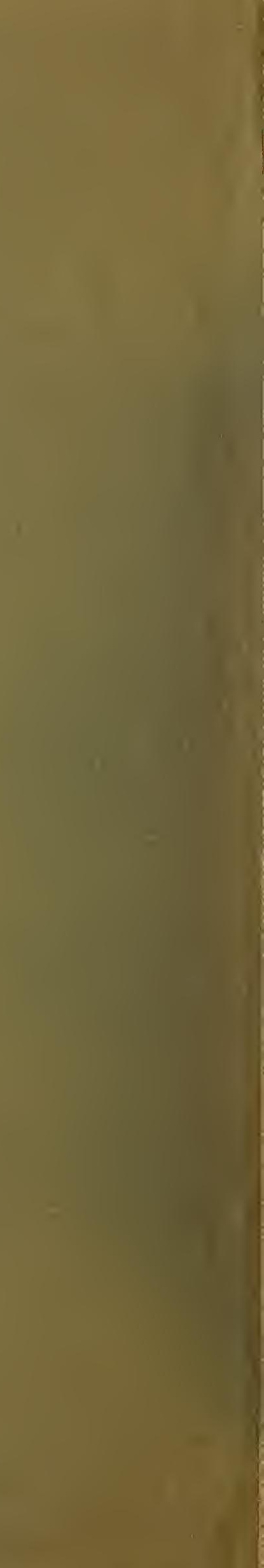




\section{FORESTRY IN QUEENSLAND.}

\section{STATEMENT}

PREPARED FOR

THE BRITISH EMPIRE FORESTRY CONFERENCE.

$$
\text { LONDON: JULY, } 1920 .
$$

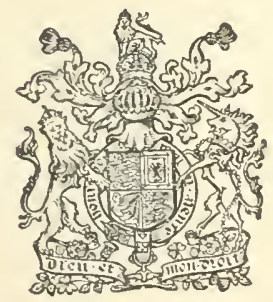


Digitized by the Internet Archive in 2010 with funding from University of British Columbia Library 


\section{FORESTRY IN QUEENSLAND.}

\section{Statement prepared by the Queensland Forest Service.}

\section{PART I.}

\section{GENERIL DESCR!PTIOY OF THE ('OUNTRY.}

The State of Queensland comprises an area of 670.500 square miles. Of this the coastal watershed cmbraces approximately 350.000 sfune miles and the interior plain country, drained by tributaries of the Murray River and Lake Erre, about 320,000 square miles.

For the most part the Dividing Range is a chain of low hills, except in the sontl, in the Darling Downs where the elevation range from 3,000 to j.000 feet. Along practically the wlole length of the east coast and leaving only a small belt of flat littoral however there is a well-defined range, broken to allow of the exit of the larger coastal rivers; this range is generally of higher elevation than the Dividing Range, and attains an elevation of 5,000 feet in the Bellenden Ker Range near Cairns on the north-eastern coast.

There being no mountains in Queensland extending beyond the permanent snow line, the rivers are dependent on the rainfall. Thus the coastal rivers fed by the Pacifie Ocean precipitation of 30 to 140 inches per annum are gond permanently flowing streams, while the watercourses of the interior with rainfall of 5 inches to 25 inches per annmm are completely dry in dronght seasons.

From a geological point of view Queensland may be divided into two great parts, occupying nearly equal areas, but possessing very different phrsical features. One of these extends along the eastern coast, from the New sonth Wales border northwards to the 12 th parallel of latitude, has an average width of abont, 200 miles from east to west, and is well watered and timbered. To this division also belongs an area in the north-west portion of the State, viz., in the Burke district. extending from the extreme north-west sonthwards to Cloncurry and Bonlia. The loftiest mountain ranges oceur in this division, the remnants of wat was once a high tableland, the highest peak. Bellender Ker, attaining an elevation of $5.1: 20$ feet.

This region consists of stratified rocks of different ages, from the oldest Palæozoic -the exact age of older roeks has not ret been determined-11], to those of recent origin. There are also large areas of granites, porphyries part ly of igneous and partly of metamorphic origin. as well as other intrusive and interbedded igneons rocks. It is in this division that most of the mineral wealth of the state exists.

The other large division. known as the WTestern Interior, consists almost cntirely of the Lotrer Cretaeenns Rocks overlaid nnconformably in places by the Desert Sandstone, which is of Upper Cretaceous Age.

The division, locally known as the Rolling Downs formation, presents a vast area, in parts of almost treeless plains, with here and there elumps of "Gidya "serub.

The rainfall over this division, more especially in the south-west, is small. The river beds are generally dry.

On the coastal belts of Qneensland on which the bulk of the softrood and cabinet-wood timbers, the soils have in the main been derived in places and indieate generally the nature of the strrounding roeks. The extensive deep and red soils of the high plateanx smeln as the Atherton Tabletand arise eliefly from the decas of basalts, andesites and allied roek trpes: the black soils oeemp the areas subject to Hooding and the red and chocolate soils the drained hillsides. The sandy soils originate from the deeomprsition of the sandstones and allied types: $\quad$.g. . the (ivmpie. formation covering a large part of the south-eastern corner of the state. The clay soils are due to the deeompesition of Paleozoic slates, and the light loams originate from the granites and from mingling of soils by stream action from dark and sandy rocks associated in the sane district. The interior country is for the most part formed of sedimentary soils orer sandstone. These are black on those areas subject to

(B1456) Wt. P1239-117. 150, 1/21, Sir J, C. \& S. Gp. 32. 
periodieal flooding and red and grey on the higher and drier areas. This belt extends practically from Cape Jork covering the western side of the peninsula to the New South Wales border and represents by far the greater part of Queensland, with exclusion of the belt near Cloncurry noted.

As hefore mentioned the rainfall varies considerably. The eoast belt fares best, the fall varying from 30 to 140 inches ammally, while in the west the annmal averages are from $\tilde{5}$ inches to 30 inches per annim, the latter being generally experienced moler the sliadow of the coastal ranges.

Generally speaking, the tropical north experienees much heavier rainfall than the south : this fact influences the growth of timber to a considerable extent. Here the forests suffer from periodieal eyclonic visitations.

The elimate is generally temperate, mean temperatures on the coast varying from $52^{\circ}$ to $78^{\circ}$ in the winter and from $73^{\circ}$ to $86^{\circ}$ in the summer.

\section{PART II.}

\section{MAIN TYPES OF FOREST GROWTH.}

Simmer rains and winter dronghts, accompanied by excessive evaporation, both differentiate the forestry problems of Queensland from those of the other States, and at the same time give now eharacter to the wooded vegetation.

In addition to extensive areas of more or less open hardwood, Queensland possesses the most important softwood resources of the Commonwealth.

Between the two types of forest there exists a sharp line of demareation.

The Softwood Forests. - This type, known in the vernacular as " serub," occupies the soils of high moisture content of the thirty to one hundred inch rainfall Jelt fringing the long stretch of coast. It hugs the alluvial bottoms and the rich rolcanie highlands and is of patchy distribution. Actually a jungle type, the density is high and the mixture ordinarily consists of a hundred various species, the majoity of which are small shade bearers of the lower storey, really medium hardwoods. The natural standards of the type furnish the principal timbers of Queensland.

There are several sub-types, the most considerable being the Aranearia mixture.

The Aroucuria Sub-Type.-This sub-type is comparatively abundant in the sonth-west eorner of the State but rarely extends northwards of Gladstone. The dominant sprecies are "Hoop Pine" (Araucaria Cumnimghamii) and Bunya "Pine" (Armonia Biduilli). The natural stand varies between 10 to 20 trees per acre in mixture: with miscellaneous sorts. The biggest trees furnish 11 to 6,000 feet of sawn timber. The timber is sold as Queensland Pine without diserimination of species, and furnishes the ehief huilding wood of the Nitate. It is the aceepted timber for butter boses and is achieving favour as a plywood. Specinens of Hoop Pine. with from $10 \%$ to $20 \%$ moisture gave weight $30-37 \cdot 5$; modulus of rupture 14,7009,750 ; crushing $8,480-6,750$.

Probably there are over $1,000,000$ acres of this trpe in the state in patches and the stand of mature timber of the speeies will measure between one and two thonsand million suyer feet, $\log$ measurement.

Associated trees are:-

Yellow wood (Flimerwia Oxlcyaná).

Crow's Ash or Queensland Teak (Flindersia Australis),

iThite Ash (Flindersin schotliana),

all valuable hardwoods of $40-60$ lh)s. weight per eubic foot.

Otl ers are White Becch (Gmelina Leichardtii), perhaps the finest earving softwoud in Australia, now very rare: Bally Gum (Litsca reticulata), second only to White Becch for each of working and carving; Pink Poplar (Euroschinus falcatus) a light softwook, fairly plentiful, l,ut not much used owing to seasoning diffienlties, and Crow's foot lilu, also plentiful, " "serub" hardwood with an "Oak-grain," suitable for staves and axe handles. 
The Iumgle sub-type.-As the moisture content inereases the Araucarias are displaced by the more rohust moisture-loving speeiss, among which the natural orders Meliacere and Laminex are strongly lepresented. The trose achieve large dimensions, and provide the more important of the cahinet works. In ble Killarnol "serubs" of the soutl-west corner the volcanic lighlands support a limited textent

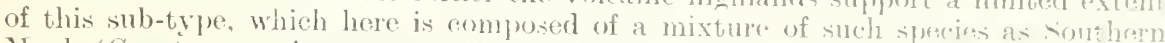

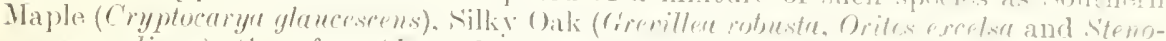

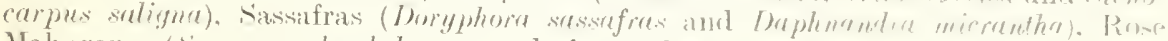

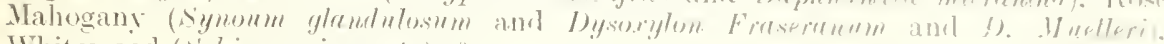
Whitewood (schizomer omalu). \&e.

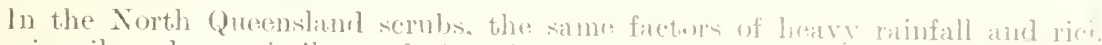

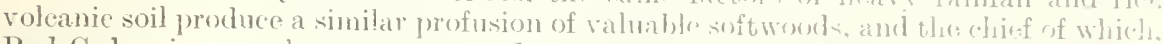
Red Cedar, is now almost cut ont. Its suceessor in popular farmer is Maple (Flindersia Chatamaima), of whieh five or ten yoars smply remains. This is a fine,

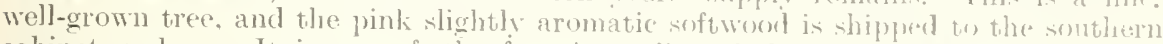
cabinet makers. It is one of the fow Australian timbers suitable for rifle stoche and aeroplane propellers.

Other important Northern woods are:-
Silkwood (Flindersin Mazlini).
Kamri (Agathis Palmerstomi).
Satinwood (Dysoxylon. Pettigreminumm).
Silky Oak (Cardwellia sublimas).
Blaek Walnut (C'ryptocarya Pelmerstomi).
Fellow Wralnut (Cryptocurya Bitmerofti).
Bally Gum (Blepharocaryu incolucrigeau).
Candlemut (Aleurites moluccana).
Black Bean (C'ustrmospermum Austrule).
Pencil Cedar (Luemure yalactoxylom).
Cairns Hickory (Flindersie Iftlainna).

The Harduood Forests. The hardwood forests ane widespread, alternating witl the Araucaria forests of the moist somth-eastern corner, and with the ("ypresi Pine serubs of the dry west. As the arailable moistme derereases, the forrests becomm. more open, and more valuable species troj) ont and the piold per ace hecomes lom. The forests are prejonderatingly Eucalyptian, with some admixtmre of other Myrtaceous and Loguminous speroies.

On the moist sands of Fraser fistand and the alluvial buttoms of the sunth-east. corner, the association is one of

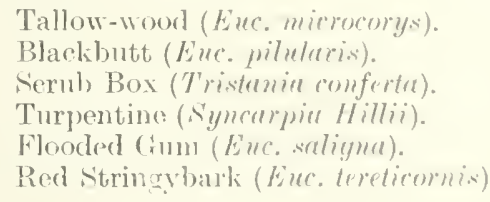

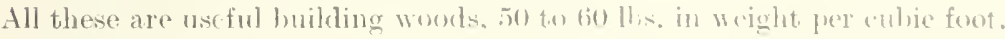

On the drier ridges of the eoast and near west. Inombarti (Eur. puniculalu. F.

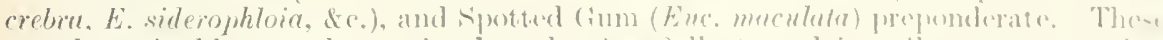

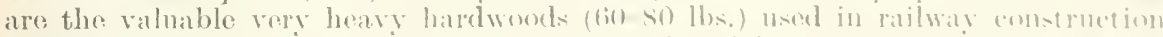

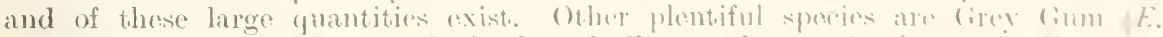

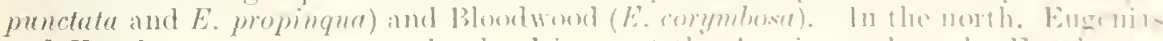

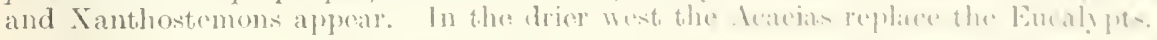

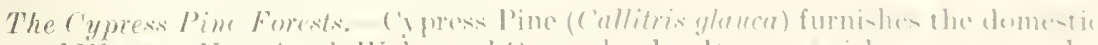

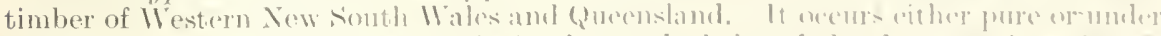

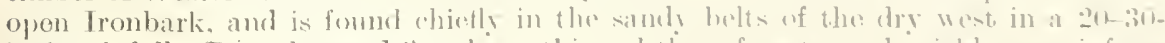

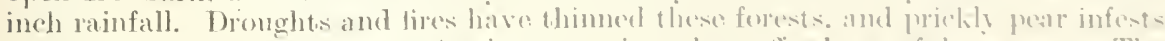

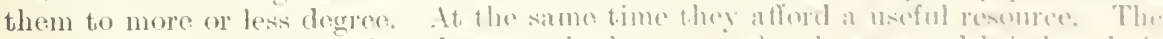

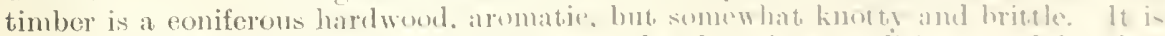

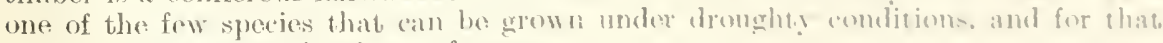
reason has an especial value to foresters. 
PAR'T III.

Area Covered by Existing Forests.

TABLE 1.

Statement shouing the Total Area of Forest and the percentage of the Land Area covered by Forest.

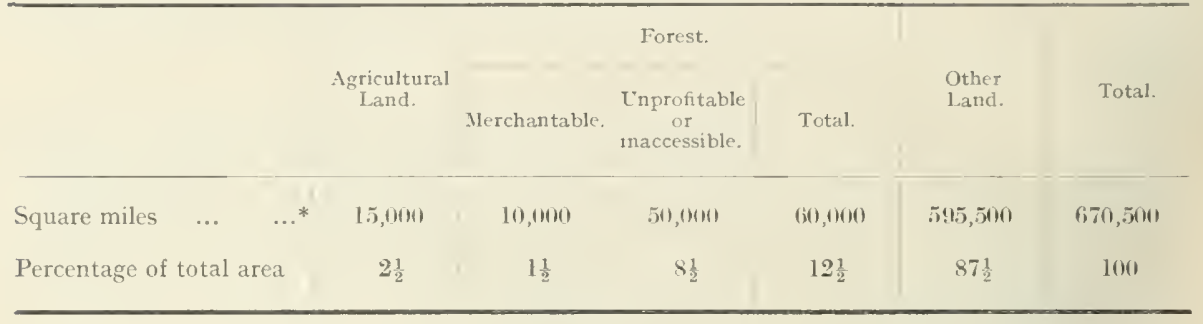

* Approximate only - no satisfactory survey has been made ; only 1,250 square miles are under crop in Qucensland, or 0.17 per cent. of the total area.

\section{PART IT.}

Notes on the IMPORTaNt Tmbers.

\section{Arancaria Cunninghamii-Hoop Pine.}

This timber is the chief softwood of Queensland, and is unirersally used for all inside purposes. It is excellent for joinery and cabinet purposes and staves, and it is the accepted timber for butter boxes. In the railway workshops it is nore used than any other timber for sheeting, flooring, panelling, framing, and finishing of carriages, and also for the deckis of sheep trucks.

specimens with from 10 to 20 per cent. moisture gave weight $30-37 \cdot 5$; modulus of rupture 14,700-9,750; crushing 8,450-6,750.

\section{Araucaria Bidwilli-Bunya Pine.}

Occurs with hoop pine over a very restricted area between Grmpie and Bunya Nomntains, but in much smaller quantities. It is cut and sold indiscriminately with hoop pine, but is preferred for staves and building motor boats.

specimens with $11 \cdot 6$ per cent. moisture gave weight $31 \cdot 5-33 \cdot 7$; modulus of rupture, $14.150-13.700$ : erushing $8,120-7,530$.

\section{Aguthis Palmerstoni-Kauri Pine.}

The timber is exported either in the log or in wide boards, and for local building purposes is to the north what hoop pine is to the sonth. Like the hoop and Buyana pines. it is very liable to attackeby borers if left lying in the serub. In the railway workshops it is well thought of for cabinet work, panelling, and framing. and, after red cedar, is the most suitable wool for pattern making. Favoured also for building light boats.

\section{Callitris Spp.-Cipress Pines.}

The botanical determinations of speeies of this genus still form a subject for debate. They occurred formerly in fairly large quantities in the dry south-western districts, where, howerer, the effects of intting, fire, grazing, dronght, and pricklypear have rendered them comparatively searee. Ther yiclded the bulk of the timber nsed in the sollth-western districts, the wood being, ferluips, the most durable sof wood in the world and white-ant resistant.

Western crpress with $33 \cdot 2-36$ per cont. moisture gare weight $50 \cdot 5$; modulus of rupture $5.120-4,(920$; crushing $6.130-4,4.00$.

\section{Eiscalyptus poniculatu-Gres Ironbark: and Euculyptus crebra-Narrow-leaved lronbark.}

They are the most lighly esteemed of all hardwoods for general building purposes and are specially songht after by the railway department for all purposes where great strength is required, such as girders, corbels, headstocks, \& e, in bridge building 
and sole bars and umelerframes for wagroms and carriagres. preferred for sprolises

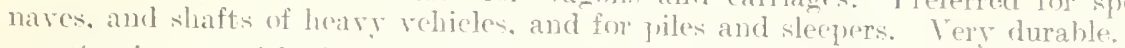

specinters with from 17.7 to $25 \cdot 2$ per cent. moisture gave weight $65-75$ :

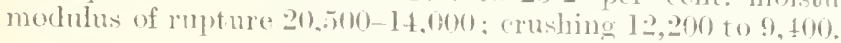

Arerage life of $2 .(1.30,000$ sleepers, replaced ruring 15 ? years, was $22-3 \%$ years.

Eucalyptux maculatr-Cirstted Gim.

The pale brownish wood ranks secoud only to Grey Ironbark as regards strengtl. and is similarly nsed, except in contact witl the gromed. The timber being of a somewhat greasy nature is favomed for slidding.

specimens with $18 \cdot 4-30 \cdot 3$ per cent. moisture gave woight 65.7-76-1: modulus of rupture $20,500-13.600$; crushing $11.250-9,000$.

Average life of 77.000 sleepers, replaced during 18 ? rears, was 17.41 years.

Eucalyptus microcorys-Tallow-wood.

The yellowish somewhat greasy timber is of excellent quality, particularly for all purposes exposed to weather, and is speeially in request for slepers and reranda posts and flooring. In the railway workshops it is used for pillars of corered wagons and for wagon sheeting. Tery dirable.

Specimens with $14-54$ yer cont. moisture gave weight 58-75; modulus of rupture 18,200-9,900; crushing 10,500-6.800.

Average life of 11,000 sleepers, replaced during $18 \frac{1}{2}$ years, was 17.52 years.

Eucapyltus Pilularis-Blackbutt.

The light greyish wood is an cxtremely useful general building timber, and in the railway worksops is used for wagon sheeting: being very straight in the grain, it is much sought after for splitting into rails and palings: somewhat subject to gum veins.

Specimens with $20-5.5 \cdot 7$ per cent. moisture gave weight $56-71$ : modulus of rupture $16,200-12,000$; crusing $10,450-6,300$.

Arerage life of 11.000 sleepers, replaced during $18 \frac{1}{2}$ years, was 15.81 years.

Eucalyptus propinqua-Grey Gum.

The red wood is of very fine quality, and is muels faromed when logs are reasonably sound. [seful for general building purposes and sleepers. Very durable.

Specimens with $21 \cdot 8-35 \cdot 7$ per eent. moistme gave weight $70 \cdot 1-7+\cdot 4$ : modu us of rupture 19,700-14,60(1): crushing $11,000-6,800$.

Average life of 19.500 sleepers, replaced during $18 \frac{1}{2}$ yars, was 13 years.

Eucalyptus resinifera-lied stringybark.

The straight-grained rod wood is one of the most pepmlan hardwoods for houne building, particularly for weather boards: used also for wagon wheeting. Rather subject to pinhole borers.

Specimens with $27 \cdot 8-46$ per cent, moisture gave weight $63 \cdot 4-72 \cdot 2:$ : modulus of rupture $20,300-13,800$ : (rushing $10,600-8,200$.

Average life of 193,000 secpers. replaced during $18 !$ years. was 17.95.

Eucalyptus acmenioides - Yellow Niringybark.

Wrood, gellowish. cut and sold with other liardwoods for genelal purpusen but not specified for particular uses.

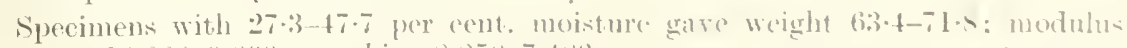
of rupture $14.000-9 .(30)$ : erushing $8.5 .511-7.414$.

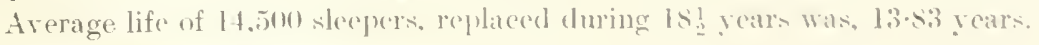

Eucatyptus corymbose - Reel Bloodwoud.

Perhaps the most widely spread Eucalyptus in curenshund, reaching its lues development on the somth wist. 
Thood, deep red, particularly subject to reins, on aecount of which it is rarely, if erer, sawn. Highly csteened for fencing. house stumps, and sleepers, being the most dumable luardwood in Queensland, but its life as a sleeper is diminished by its tendency to shell off along the reins.

specimens with 20-5:3 por ceut. moisture gave weight $55 \cdot 3-73 \cdot 3$; modulus of rupture 23.200-9,700: erushing 12.300-7.100.

Average life of 1:28,500 sleepers, replaced during $18 \frac{1}{2}$ years, was $17 \cdot 06$ years.

siyncarpie laurifolia-Tumpentine.

The pinkish hrown wood is, for a hardwood, eomparatively light and easy to work, and of great durability. On aceomnt of its large shrinkage and tendence to warp in small sizes, it is not faroured hy samillers, but is rery snitable for deeking of wharves and for large beams-it being very fire-resistant; used for sleepers and for fender piles of wharves. but deserving generally of far greater attention than it has ret received. In the railway workhops it is cut for wagon sheeting and pillars.

speeimens with $27-43 \cdot 4$ per eent. moisture gave weight $63 \cdot 4-68$; modulus of rupture 15.600-8,600; erushing 9.990-7.480.

Arerage life of 29,000 sleepers, replaced during $18 \frac{1}{2}$ years, was $19 \cdot 60$ years.

Tristania conferta Serub Box.

Abundant on the south coast and on Fraser Island where it is probably more plentiful than any other speeies of this order.

Though rery durable and used largely in New South Wales, it rarely is sawn in Queensland, probably owing to its tendeney to warp in small sizes.

\section{('edrela austratis-Red Cedar.}

The wood, of a deep' red eolour, is light, soft, easily worked, and aromatie, and extremely dmable when exposed to the weather. It is the most valuable eabinet and decorative wood in Australia. Largely used for the eonstruetion of racing boats, and when comparatively plentiful and cheap was preferred to all other woods for pattern-making.

Sjpecimens with 12 per cent. moisture gave weight $33 \cdot 5$; modulus of rupture 11,500 ; crushing 6,600.

\section{Flindersia anstivalis-Crow's Ash.}

A hard, oily, yellowish brown wood, of great durability, used elniefly for flooring ballrooms, skating rinks, and verandas, and for sheeting of railway wagons; suitable for staves. handles of tools, and bearings.

Green specimens with an nnrecorded pereentage of moisture gave weight $58 \cdot 3-61 \cdot 7$; modulus of rupture $13,300-15.800$; crushing $6,800-7,600$.

\section{Flindersia Chatawaina-Red Beeeh or Maple.}

The pink slightly aromatie timber is used in the north for general building purposes, sheh as weather boards, chamfer boards and studding plates, but is chiefly shipped south as a very valuable eabinet wood-now the most popular in Sunth Queensland. Suitable for rifle stocks, airship propellers, and boat building, and used in railway eariage eonstruetion for pillars, framework, moulding, panels and general fumishings. The most suitable wood for wheels of railway tricyeles. A very fair bending timber.

\section{Dysoxylon Fraserunum-Rosewood.}

A red, fragrant wood, extrenely durable and of great beanty for eabinet purposes when cut tougentially.

\section{rardwellia sublimis-Bull Oak, Brown Oak, Silky Oak.}

This wood is now the common "silky Oak" of the trade, and is used largely for cabinet work. Tn the north it is used for stares and for general building purposes, especially in the Innisfail Jistriet. where it is cut into seantlings. weather boards, chanfer boards, studrling. lining boards, \&e. It is a good timber for bending into soats of vehicles, and is in gencral use in railway carriage construetion for bent roof sticks, mouldings. framework, and panelling. Air dry weight abont 38. 
Litwet reticulate and ferruginea- Bally (amo (Lantacen).

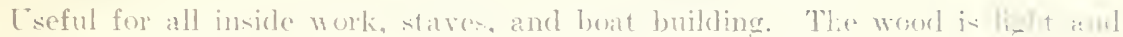

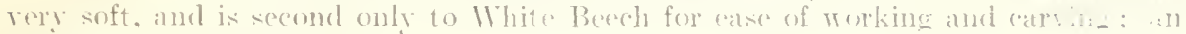
excellent ribinct timbor.

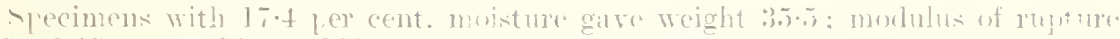
$11.1 .50-9.5 .50$ : (rolshing $6.100-5,2110$.

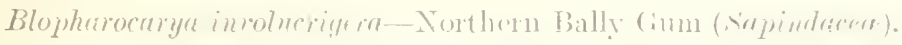

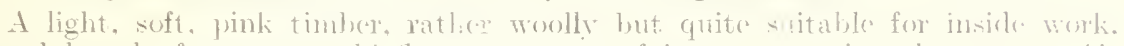
Is used largely for stares. chiefty on account of its comparatire cheapmes. Air dry weight abont fli.

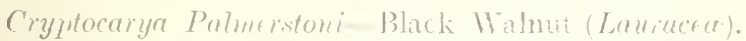

Wood, rich bromn, moderately hatel and heavy. of great beanty. Throms well and takes a fine polish. but is risliked hy sam milleis oning to it injuriots effect on the saws. Air dry weight about 49.

Tarrietia argyrodentron-Ciom"s Font Elm (siferentiacue).

The brownish wood is straight-grained and beantifully marked witen ont on the quarter. and should find a mse for cabinet. purposes and the panelling of horses and railway carriages. It was seleeted ly an American tool manufacturing firm from a series of samples comprising Black Bean. Red Bean, and Rerl C'edar, as the most suitable for turning into handles for combination tools.

It is not durable when exposed to weatlier, and beeomes fairly harl when rery. Whon green it is tough and rery elastie, but is said to become brittle when thry. though axe handles turned from this wood and preserved in the Forests Otfiee for over seven years show no signs of brittleness. The southern rariety was once used for stares. when it was commonly known as starewood.

Specimens of the variety trifuliolatu with $1 ১ .2$ per cent. moisture gare weight 61.2-62.4; modulus of rupture $14.00(-16.800)$; (rushing $18.800-10.50(1)$; but the air dry weight of an office specimen of peraluta was only 51.

\section{Castanospermum australe-Black Bean (Legmminosce).}

Wood of a rieh dark brown with light streaks, only moderately hand and heary. and rery durable. Formerly used in the north largely for hionserbuilding and fencing, but mueh too valuable for steh purposes. An excellent cabinet wood of great beauty, used for framing. moulding. and panelling of railway carriages. tir iry weight about 46.

\section{PART Y. \\ OW XERSHIP OF FORESTS.}

TABLEII.

Classification of the Forent Area by Ommerwip.

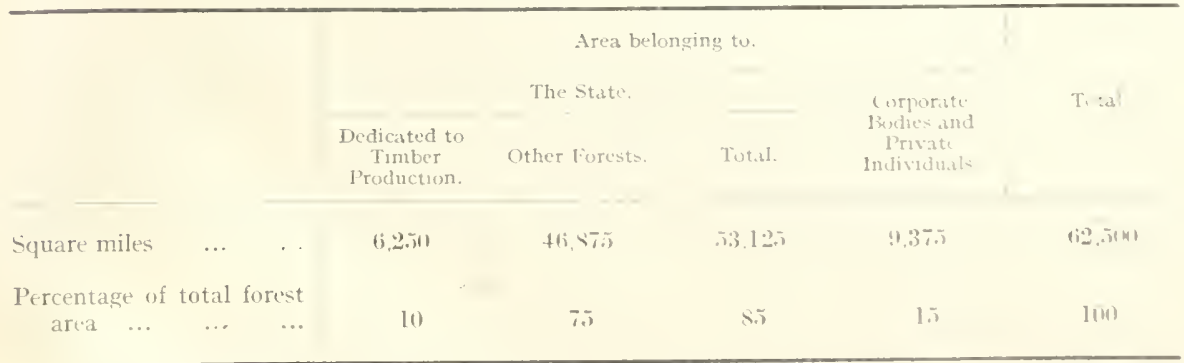

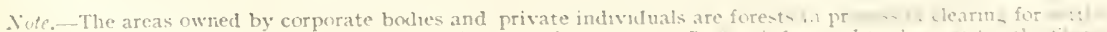
ment purposes and not for forestry. They snpply at preseme it, of the tuit umber witor the 5 


\section{PART II.}

The Relatioxship of the State to the Forests.

6. The forestry legislation of Qneensland has been enacted under two measures : 1. "The State Forests and National Parks Act of 1906."

2. "The Land Act of $1910 . "$

and by means of regulations under both enactments.

The State Forests and National Parks Act provides mainly for the establishment of State Forests and National Parks, i.e., permanent forestry reservations which may not be interfered with except by authority of an Act of Parliament. Special provision was made in the Act for the granting of Special Leases and Occupation Licenses under the Lands Act orer State Forests and National Parks; and the mining laws are not affected by the Act. The Act also authorises the making of Regulations to administer the State Forests and National Parks.

Regulations under State Forests and National Parks Act.

The regulations made under this Act provided for :

1. The control of the State Forests and National Parks by the Director of Forests.

2. The making of working plans in respect thereof.

3. The methods by which timber and forest produce were to be sold. therefrom.

4. The prevention of illegal acts in connection therewith, i.e., trespass, cutting timber without authority, defacement of brands, marks, \&c., careless use of fire, \&c., \&c.

5. The anthorities of forest officers to prosecute in respect of forest offences on State Forests and National Parks.

and other minor provisions.

"Land Act of 1910."

"The Land Act of 1910 ," a statute governing the leasing, sale, and administration of Crown Lands generally, contains provisions relating to the removal of timber from Reserves (temporary reservations Crown Lands, i.e., land not lawfully granterl, or contracted to be granted in fee simple; or not reserved or dedicated for stated public purposes) and certain leases.

Selectors of certain selections are given timber rights commensurate with the security and purpose of their land tenure.

The Act provides for making of regulations to govern sale of timber on Timber Reserves and Crown Lands, and affords authority of entry on lands to officers.

"The Timber and Quarry Regulations."

The Timber and Quarry Regulations of 1912 set forth :-

1. The procedure by which timber is to be sold from Crown Lands, and Reserves.

2. The minimum prices and sizes at which timber and forest produce is to be sold.

3. The conditions pertaining to removal of quarry material.

4. Requirements to be observed by purchasers and persons handling Crown timber, \&c.

5. Conditions under which animals used in forest work may be depastured. and other minor provisions re legal procecdings, \&c.

An Act is to be brought before Parliament at an early date to afford a greater measure of control of the estate to the Forest Service.

6в. At the present time in Queensland the Forest Service is not fully developed. The limited staff cannot deal with the large area of country involved, and the operations are necessarily confined to the more closely settled areas, contiguous to the chicf markets. 
Forest stations haw heen established on a number of the more accessible reserves. Houses have heen provided for officers in charge of operations. and the housing of the staffi is heing proceeted with.

\section{Forest Protertion.}

(in those areas at present moler treatment, tlie forrest. staff cleals with fires as they arise. A system of road fireloreaki is being established. and thesco compled with sulerrision, are found to be effeetive in checking forest firen generally. Fire protection wauses are inserted in timber sale agreaments and licenses wibererer necessary. Tle new tot will make provision for greater pow an of the Forest service in dealing with the fire glestion in demanding aid of forest and neighbouring sottlues and of timberencteres and timber workers on the forest.

\section{Nurseries and Plantutions.}

Forest nurseries have been established in the several main districts and the propagation of indigenoms and exotic plants is being earried forwart as ynickly as possible. Ninseries now in cxistence corer about 3 acris of gromel.

Experimental planting is also being undertaken, chiefly of Honp and Bunsa Pine (Arencuria species). An area of abont 320 ares is uncler plantation at the jurent time, and the work is being undertaken more extensirely diring the current rear.

Treatment of the present stand for the improrement of natural regeneration is also being proceeded with experimentally:

\section{Foresi Orgenisation-Rouls and Trumeays.}

Good progress is heing made with survey of forest road sistems and the construction of forest roads.

Tramway projects are also being initiated in several localities.

IVater sinply.

Water is being provided on some of the firier reserves by means of sub-artesian bores, tanks, dams. \& . Where water is a vaijable jomping plants are being installed in sereral places for nursery and clomestic rse.

\section{Timber Trading.}

The Forest Nerrice activity has extended to timber har w ing and marketing. and during the past year it has logged and sold elepartmeltally ame s.motonog square feet of timber. "ales on the stump bring the total ammal ent on (rown forest. to about $60,000,000$ square feet, Iog measurement.

\section{Aswintance to pricate forestry.}

No private forestry exists, and so long as funds for state Forestry are limited. subsidies on this aceount are madmissible.

\section{PART III.}

\section{THE FOREST ACTHORITY.}

The Fonest service of Quecusland, ats at present contet if uted, is merely a hranch

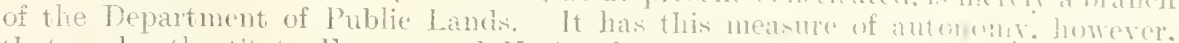
that under the state Forests and National Parks Act. the l)ircetor of Porest is

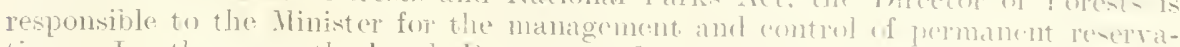

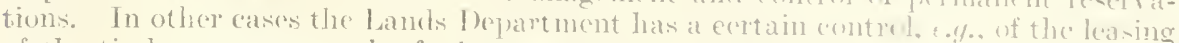

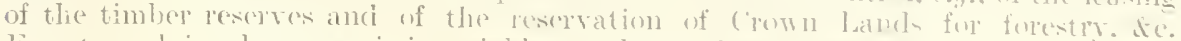

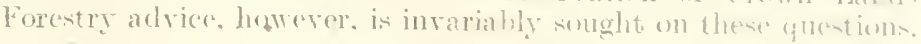

Owing to the linited forestry staft a large juertion of the stati in still -muer ised

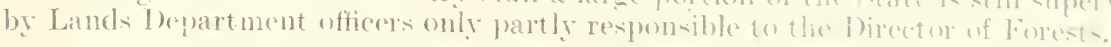

The Forest persomnel consists of the Director of Forest so whem the I)istrict

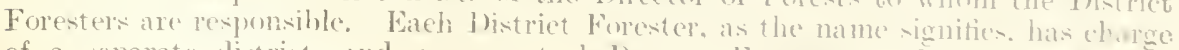
of a separate distriet. and may control Deputy foresters meter the respective 
branches of Sylviculture, Sales and Engineering, Forest Factors, Forest Rangers and Forest Guards, Forest Overseers and Foremen in charge of Reserves and working gangs and their staffs, and of Cadet Foresters, placed within his District for training. Each District Officer has necessary elerical assistance to enable him to carry out the uniform system of accounting and cost keeping, and the vertical filing of records.

A Forest Engineer is to be appointed shortly to take charge of the Engineering Branch of the Forest service.

A Forest school is being built at Imbil in Southern Qneensland, and an Instructor and Assistant are to be appointed. Short courses will then be arranged for officers at present in the Service, and a system of training of new entrants put into operation.

Education methods now being adopted are :-

1. The distribution of publications from the forest library to all aspirants to forestry knowledge, and

2. A generons circularisation among the personnel of items of forestry information and interest and of salient points from recognised works on forestry.

The system in force of compiling information has been found of great use in this regard.

Each year the Director of Forests furnishes his Annual Report to Parliament. This report covers the main activities of the Service.

Publications have been issued as under :-

"The Structure and Identification of Queensland Woods."

"Notes on the Principal Timbers of Queensland."

"Sylvicultural Notes on Forest Trees of Queensland."

"Australian Study of American Forestry."

"Finaneing of Forestry."

"Federal or State Forestry-Which ?"

"Forestry in Queensland."

"The Australian Forest Ration and its Apportionment."

Following is a statement of revenue and expenditure during the past fifteen years :- .

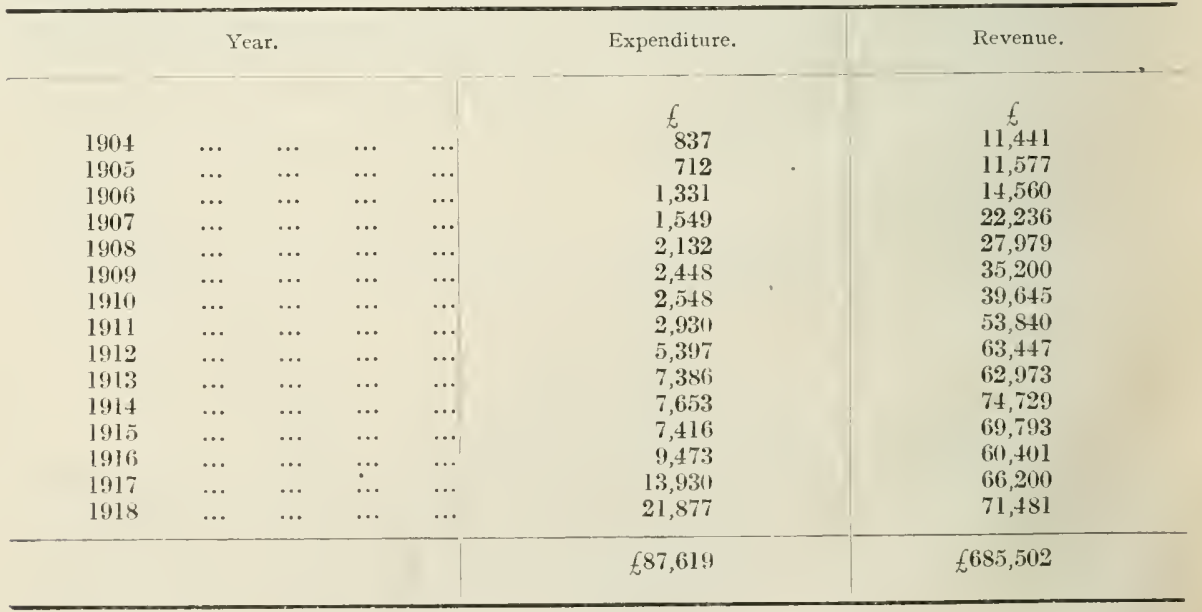

PART VIII.

Forestry Activities of Municipal and Corporate Bodies.

Private or municipal forestry is not yet practised in Queensland. 
PART IX.

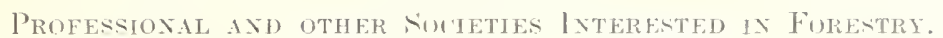

There are no such societies except those such as the Brisbare 'Timber Herchants' Association (Creek street. Brisbano), interested in tlo marlisting of timber.

PART X.

Eitcathox, Research aNd Expermestal Work.

A Forest sehnol of Forestry and Institute of sil licultural Resenteh is projected, the site to be at Imbil. Mary Valley Jine, Queensland.

Srlvicultural research and experiment are heing carrierl wit at the several Forest stations.

The work at the Forest service Office in Brisbane includes studien in wood technology and classification, and a small Timber Husem exists. Timber exhibits are prepared for display at local and foreign exlibitiuns.

\section{PART XI.}

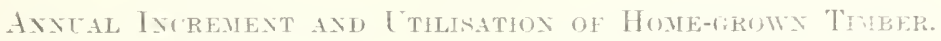

TABLF: III.

Annual Increment.

\begin{tabular}{|c|c|c|c|c|c|c|c|}
\hline & $\begin{array}{l}\text { Area } \\
\text { Syuare } \\
\text { Alles. }\end{array}$ & $\begin{array}{c}\text { Estimated } \\
\text { increment } \\
\text { per } \\
\text { Square } \\
\text { Mile. }\end{array}$ & $\begin{array}{c}\text { Tuteil } \\
2 \mathrm{Tr} \cdots \\
\text { increme it }\end{array}$ & I. : : & 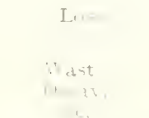 & $T=1$ & 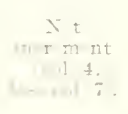 \\
\hline & & s. it. & $\therefore$ it. & s. ft. & $-\mathrm{ft}$. & $\therefore \mathrm{ft}$ & $\therefore \mathrm{ft}$. \\
\hline control ... & 10,0000 & 32,1100 & $320,(601),(4) 0)$ & $801,(0101,0000$ & $16011,(1016),(1) 161)$ & $2401,11111,111111$ & -4). $1101,1 \mathrm{~km}$ \\
\hline Other & 1.0001 & $32,(6111$ & $32,1161,80101$ & $8,1611) .11110$ & $16,(4) 111,1)(1)$ & $2 \pm, 61611,16101)$ & -.111110 .111100 \\
\hline Total & 11,111111 & 32,01001 & $352 .(11111,(118)$ & $85,111111,111119$ & 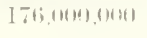 & $2(i+1,046), 0(0)$ & $x+1)+11,000$ \\
\hline
\end{tabular}

TABle $\mathrm{M}$.

Annual tritisation.

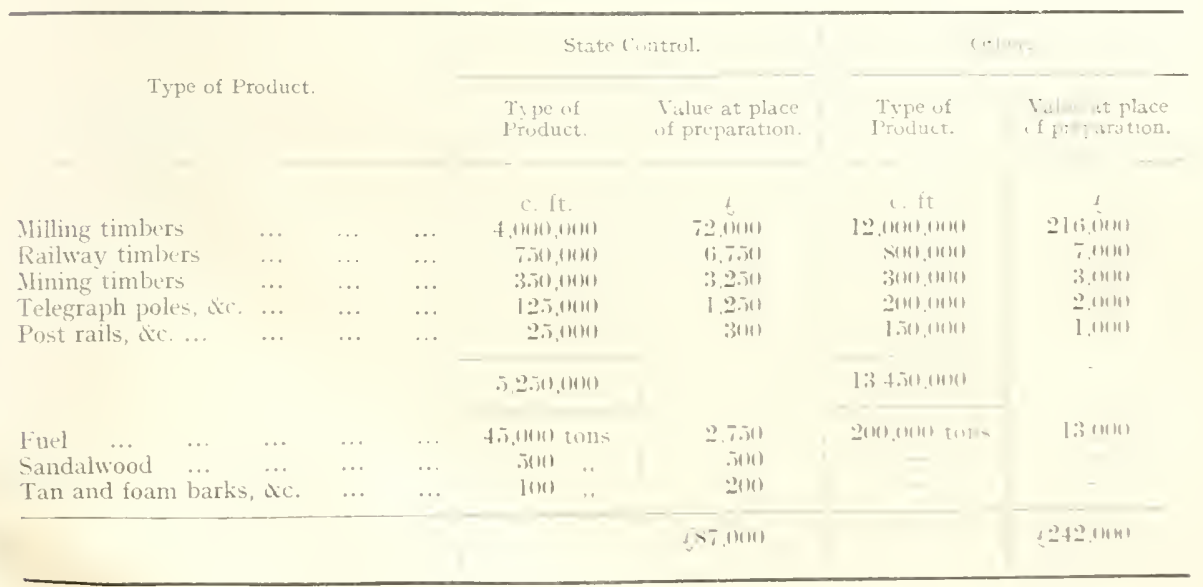


PART XII.

\section{Forest lndustries.}

In 1918 the saw milling industry absorbed $15,000,000$ eubie feet of timber; of this $9.000,000$ eubic feet was Pine, 30,000 eubic feet Cedar. and the balance Hardwoods. The value of this ent was $£ 1,3 \pm 0,000$, and approximately 3,500 lands were engaged in its manufacture.

Considerable employment is also afforded in log getting, railway, mining and pole timber getting. It is estimated that about 1,500 to 2,000 persons are engaged in these actirities.

No fignres are arailable to show the quantity of timber ent on private lands. A close approximation is a railable in respect of milling timber, and indicates that the private cut is three times that of the Crown, dne to the fact that in past times vast alienations of timber land have been made, and these are being eut into regardless of the futire.

Fnel and fencing operations are extensive, and provide employment for a large number of persons, while about 100 are engaged in the getting of sandalwood, guano, and eupania and mangrove bark. No definite figures are available, however, of valne of the products obtained.

A pulp mill was erected at Yartaman for the purpose of making paper pulp from the tops of Hoop and Bunya Pine (Araucaria sp.). Operations were eeased in the latter part of 1919 , owing mainly to water difficulties.

For volume of timber consumed in various industries, see Table IV. No other information is available.

PART XIII

Statistics as to Exports and Tmports of Tiniber.

TABLE T1.

Average Anmual Imports and Exports.

\begin{tabular}{|c|c|c|c|c|c|c|}
\hline \multirow[b]{2}{*}{ Type of Product. } & \multicolumn{2}{|c|}{ Exports. } & \multicolumn{2}{|c|}{1 mports. } & \multicolumn{2}{|c|}{$\begin{array}{c}\text { Balance, plus or minus } \\
(+ \text { or }-) .\end{array}$} \\
\hline & Quantity. & Value, f.o.b. & Quantity. & Value, c.i.f. & $\begin{array}{l}\text { Quantity } \\
\text { (col. 2- } \\
\text { col. 4) }\end{array}$ & $\begin{array}{l}\text { Value } \\
\text { (col. } 3 \\
\text { col. 5.) }\end{array}$ \\
\hline - & & & & & & \\
\hline & c. ft. & $\hbar$ & c. $\mathrm{ft}$. & $£$ & c. $\mathrm{ft}$. & $t$ \\
\hline Queensland softwoods ... & $2,0000,000$ & 500,000 & - & 一 & $>1,994,000$ & 498,500 \\
\hline American hickory & - & - & $6,001)$ & 1,5110 & & \\
\hline
\end{tabular}

Note.-Most of the exports from Queensland are to the other States.

The imports shown are from overseas to Queensland. There is no interstate timber imported. 
PART XII.

STMMARY aND OTTLOOK.

Table V'Tl.

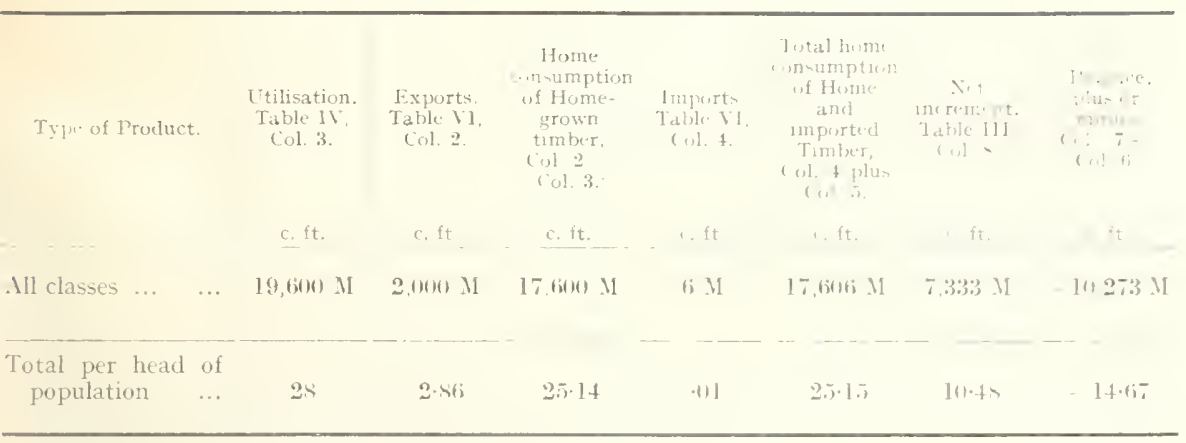

Vote-Population of Queensland, 700,000.

14c. Short stummary of steps which should be taken, \&c.

The reason for the apparent serious orercutting taking place in Queensland is the operation by private landholders who are all realising timber values immediately with no thought for the future.

As these private resources become cut ont, operators will be forcerl to go further afield on Crown Lands in search of timber.

With inereased utilisation under forestry management the amomnts lost by waste, decav, fire, \&s., will be reducerl considerably, and the net increment of the Queensland forests enhanced as much.

The position is, however, that the immediately prospective renomes of timber is barely sufficient to meet requirements at the present rates much lass to meet the inereased demand the future must hold.

The necessary steps to be taken are :-

1. Permanent dedication of not less than 6.0000000 acres Pine forest.

2. Construction of an independent Forest Service free from political control, in so far as technique and trade are concerned.

3. The provision of adequate funds for forest development purposes. 


\section{APPENDICES}

Appendix. A.

No Commissions have reported on forestry and forest questions in Quecnsland.

Appendix $B$.

"State lorests and National Parks Act, 1906," and Regulations; " Lands Act, 1910," and "Timber and Quarry liegulations."

Appentix $C$.

Annual Report of Director of Forests.

"Australian Study of American Forestry."

"The Structure and Identification of Queensland Woods."

" Notes on the Principal Timbers of Queensland."

"Financing of Forestry."

"Federal or State Forestry-Which?"

"Forestry in Queensland."

"The Australian Forest Ration and its Apportionment."

Appendix D.

No forestry literature is issued in Queensland other than by the Forest Service. 


\section{Th: book is for use in Lunary Euting ONLY and as a "Reserved" Loan}


